\title{
Leucism in Akodon affinis (Allen, 1912) (Rodentia: Cricetidae)
}

\author{
Sebastián Montoya-Bustamante ${ }^{1,2 *}$, Natalya Zapata-Mesa ${ }^{1,2}$ and Oscar E. Murillo-García ${ }^{1}$ \\ ${ }^{1}$ Instituto de Biotecnología y Ecología Aplicada (INBIOTECA), Universidad Veracruzana, Av. de las Culturas Veracruzanas No. 101, \\ Xalapa, México. Email: s.montoyabustamante@gmail.com (SMB), natalya.zapata@correounivalle.edu.co (NZM). \\ ${ }^{2}$ Grupo de Investigación en Ecología Animal, Departamento de Biología, Universidad del Valle. Calle 13 No. 100-00, Cali, Colombia. \\ Email: oscar.murillo@correounivalle.edu.co (OEMG). \\ ${ }^{*}$ Corresponding author
}

\begin{abstract}
Leucism is a condition where animals show a loss of pigments on certain parts of their skin, without affecting soft tissue, a condition that has been poorly reported for Neotropical rodents. Therefore, our goal was to report leucism for Akodon affinis, an endemic species from Colombia, and to analyze the pattern of leucism prevalence in different populations. A. affinis specimens deposited in the Mammals Collection of Universidad del Valle (UV) were examined, and any traces of leucism and its prevalence were recorded for 12 different localities where this species was found. These localities were sampled in different years. The association between incidence of leucism and sex was assessed using a Two-tailed Fisher's exact test. A total of 11 individuals from five localities displayed traces of leucism in different parts of their body (Table 1, Appendix 1), including cheeks, dorsum and venter (Figure 1). The analysis revealed that the incidence of leucism was higher in males vs. females. Traces of leucism were most frequent in the dorsum than any other part of their body. Although this species is considered as a Least Concern by the International Union for Conservation of Nature (IUCN), these findings suggest that populations of $A$. affinis might be experiencing inbreeding; however, more information is needed to establish the reproductive and survival consequences of this condition on $A$. affinis populations.

El leucismo es una condición donde los animales presentan una pérdida de pigmentos en ciertas partes de su piel, sin afectar tejido blando, condición que ha sido pobremente reportada para roedores neotropicales. Por lo tanto, nuestro objetivo fue reportar leucismo en Akodon affinis, una especie endémica de Colombia, y analizar su patrón de prevalencia en diferentes poblaciones. Una revisión de los individuos de $A$. affinis depositados en la Colección de Mamíferos de la Universidad del Valle (UV) fue llevada a cabo, donde se registró información de leucismo y su prevalencia para 12 localidades diferentes donde esta especie fue encontrada. Estas localidades fueron muestreadas en diferentes años. La asociación entre la incidencia de leucismo y el sexo se evaluó con una prueba exacta de Fisher a dos colas. Un total de 11 individuos de cinco localidades diferentes fueron encontrados con rastros de leucismo en diferentes partes de su cuerpo (Tabla 1, Apéndice 1), incluyendo sus mejillas, dorso y vientre (Figura1). Los resultados indican que la incidencia de leucismo fue mayor en machos que en hembras. Por otro lado, los rastros de leucismo fueron más frecuentes en el dorso en comparación a las otras partes del cuerpo. Aunque esta especie es considerada como Preocupación Menor por la Unión Internacional para la Conservación de la Naturaleza (UICN), estos hallazgos sugieren que las poblaciones de $A$. affinis pueden estar sufriendo de endogamia; sin embargo, es necesaria más información para establecer las consecuencias de esta condición sobre la reproducción y supervivencia de las poblaciones de A. affinis.
\end{abstract}

Key words: Colombia; Colombian grass mouse; conservation; endemism; melanin; population.

(C) 2017 Asociación Mexicana de Mastozoología, www.mastozoologiamexicana.org

\section{Introduction}

Leucism is a condition where animals show loss of pigmentation on certain parts of the skin, without affecting soft tissue (Buckley 1982). In mammals, pigmentation results from the synthesis and distribution of melanin (Hearing and Tsukamoto 1991), which depends on several enzymatic factors that modulate pigmentation, especially tyrosinase (Hearing and Tsukamoto 1991; Oetting et al. 2003). Melanin plays important roles, including protective coloration, communication, sexual selection, absorption of free radicals and body protection from ionizing radiation (Levine and Krupa 1966; Hearing and Tsukamoto 1991; Caro 2005; Camargo et al. 2014). Leucism has been observed in small mammals such as bats (Velandia-Perilla et al. 2013) and rodents (Oliveira 2009; Camargo et al. 2014; Brito and ValdiviesoBerneo 2016). However, in Neotropical rodents, this condition is barely known, and it has only been reported in a few species (reviewed by Brito and Valdivieso-Berneo 2016).

The Colombian grass mouse, Akodon affinis (Allen 1912) (Cricetidae), is a medium-sized Neotropical rodent charac- terized by uniform dusky brown upper parts with yellowish hair tips, giving an overall olivaceous effect, and dark grayish brown venter with olivaceous hair tips (Pardiñas et al. 2015). This species is endemic from the Colombian Andes and is the only representative of the genus in this country (Pardiñas et al. 2015; Ramírez-Chaves et al. 2016). Considering the limited information on the population and natural history of this species (Pardiñas et al. 2015), our main goal was to report leucism in Akodon affinis for the first time, and its incidence in populations inhabiting different Andean mountain ranges.

\section{Material and methods}

A comprehensive examination of the Akodon affinis specimens deposited in the Mammals Collection of Universidad del Valle (UV), Colombia, was carried out. We recorded information on the incidence of traces of leucism for the 12 different localities where this species has been recorded. These localities were sampled across different years, mostly during fieldwork practices of Biology courses at UV, using 

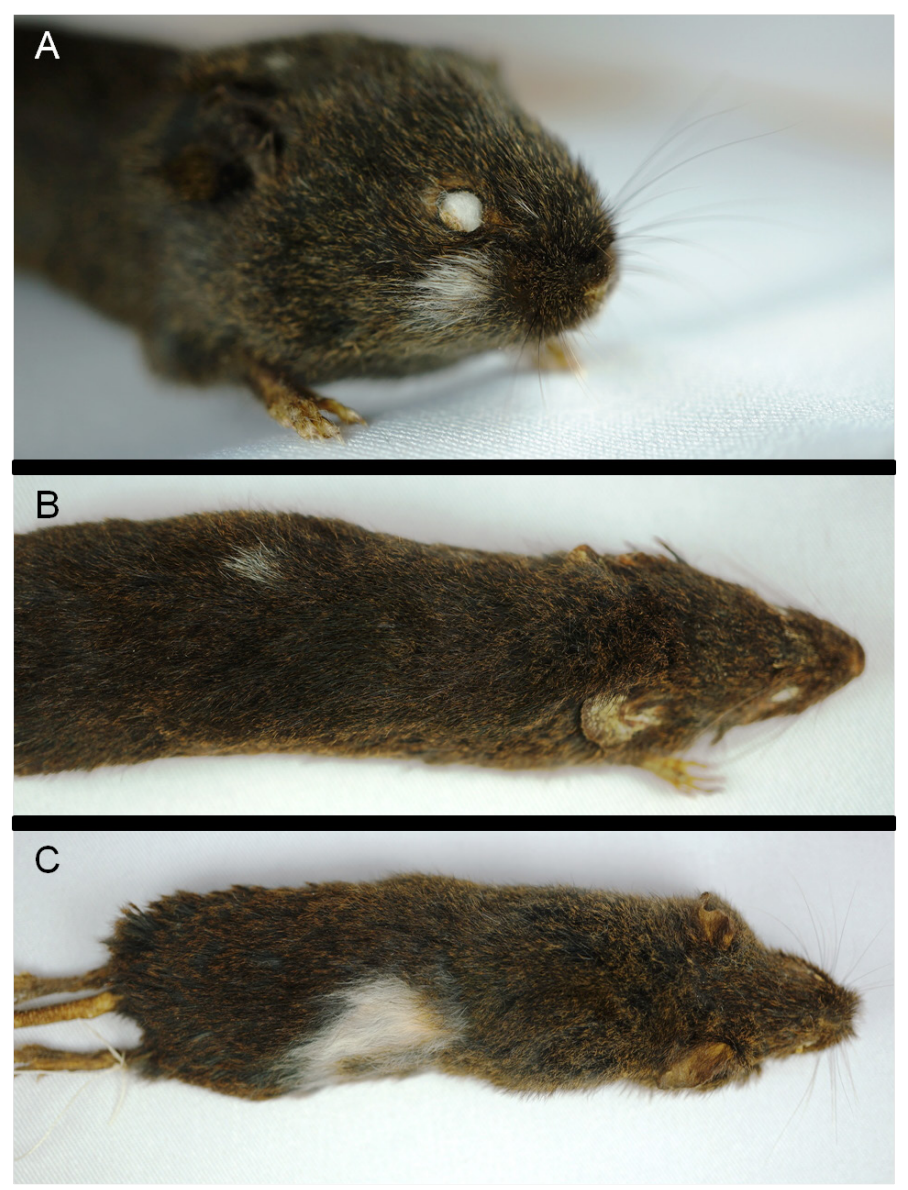

Figure 1. Leucism in individuals of Akodon affinis from Colombia: A) Spots on the right cheek and next to the ear (UV 14,440). B) Spot on the dorsum (UV 13,343). C) Wide spot from dorsum to venter (UV 12,025). Photographs by L. Ruano.

100 to 200 Sherman traps (200 in most cases, V. Rojas-Díaz pers. comm.). We used a two-tailed Fischer's exact test to explore the association between incidence of leucism and sex. For this analysis we only considered the localities (with all the individuals in each) where leucism was detected.

\section{Results}

A total of 11 out of $96(11.46 \%)$ individuals were found to show traces of leucism in different parts of their body (Table 1, Appendix 1), including cheeks, dorsum and venter (Figure 1). The dorsum was the part where most individuals

Table 1. Traces of leucism in individuals of Akodon affinis (Allen, 1912) from Colombia.

\begin{tabular}{|c|c|c|c|}
\hline Locality & Specimen & Sex & Traces of leucism \\
\hline \multirow[t]{6}{*}{ Florida } & UV 3570 & $\partial$ & Multiple spots on dorsum and rostrum \\
\hline & UV 3571 & $0^{2}$ & Multiple spots on dorsum \\
\hline & UV 3573 & $\hat{\jmath}$ & Multiple spots on dorsum \\
\hline & UV 3575 & $\hat{o}$ & Multiple spots on dorsum and left cheek \\
\hline & UV 3578 & q & Spot on dorsum \\
\hline & UV 10867 & $\sigma^{2}$ & Spot on left cheek \\
\hline Palmira & UV 12025 & $\partial$ & Wide spot from dorsum to venter \\
\hline Buga & UV 12414 & $\hat{o}$ & Spot on dorsum \\
\hline El Cairo & UV 13343 & 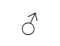 & Multiple spots on dorsum \\
\hline \multirow[t]{2}{*}{ Pereira } & UV 14440 & $\partial$ & Spot on right cheek and next to the ear \\
\hline & UV 14488 & 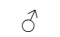 & Spot on left cheek \\
\hline
\end{tabular}

showed traces of leucism ( $n=8)$, followed by cheeks $(n=5)$ and venter $(n=1)$. Some individuals presented more than one part of their body with traces of leucism. The analysis showed a significant association between sex and leucism (odds ratio $=8.965, P=0.021$ ), with males having a higherthan-expected incidence of leucism. Leucistic individuals were collected at five different localities (Appendix 1) from the Western and Central Andes of Colombia (Figure 2). The incidence of leucistic individuals per locality was high (Table 2), but fluctuated over time. There were more localities with leucistic individuals in the Central Andes than in the Western Andes (Figure 2).

\section{Discussion}

This paper reports, for the first time, information on leucism in Akodon affinis populations and its incidence over time in several localities. Our results suggest that the presence of leucism in the sampled populations is as high as the incidence found for Akodon mollis in Cordillera de Chilla, Ecuador, a highly fragmented habitat (Brito and ValdiviesoBerneo 2016). The incidence of leucism in A. affinis is significantly associated with sex, and appears mainly on their dorsum and rostrum. However, there is insufficient information to assess the potential influence of leucism on survival (visibility to a predator) or reproduction (sexual selection).

It has been proposed that leucism can be the result of skin wounds in burrowing rodents of the Family Geomyidae (S. T. Álvarez-Castañeda pers. com.). However, since

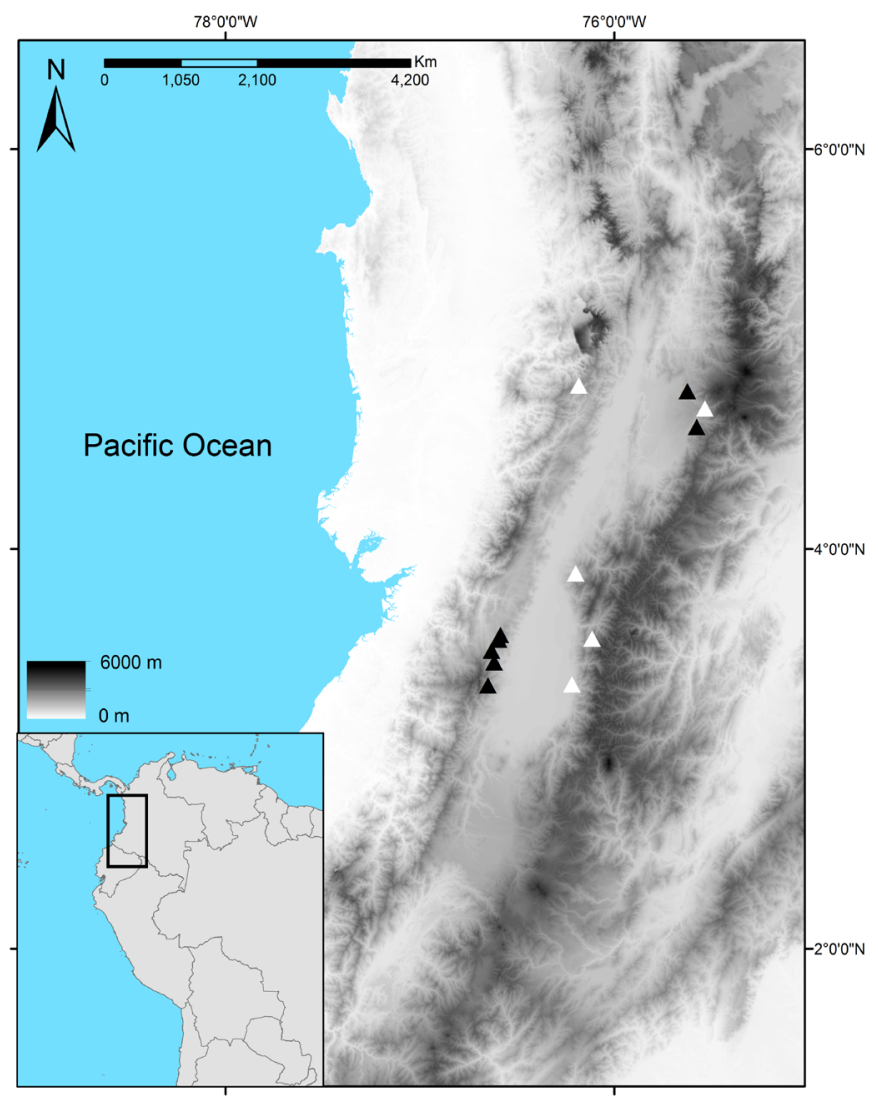

Figure 2. Collection localities of Akodon affinis in the Colombian Andes. White and black triangles depict localities where individuals showed traces or no traces of leucism, respectively. 
Table 2. Proportion of leucism observed in populations of Akodon affinis throughout the years.

\begin{tabular}{|c|c|c|c|c|c|c|}
\hline Andes & Locality & Year & $n$ & $\begin{array}{c}\text { Leucistic } \\
\text { individuals }\end{array}$ & $\begin{array}{l}\text { Proportion } \\
\text { of leucism }\end{array}$ & $\begin{array}{c}\text { Total per } \\
\text { locality (n) }\end{array}$ \\
\hline \multirow[t]{9}{*}{ Central } & Pereira & 1989 & 7 & 0 & $0 \%$ & $10.53 \%(19)$ \\
\hline & & 1990 & 3 & 0 & $0 \%$ & \\
\hline & & 2013 & 9 & 2 & $22.22 \%$ & \\
\hline & Buga & 2001 & 2 & 1 & $50.00 \%$ & $14.29 \%(7)$ \\
\hline & & 2004 & 5 & 0 & $0 \%$ & \\
\hline & Florida & 1983 & 9 & 5 & $55.56 \%$ & $23.08 \%(26)$ \\
\hline & & 1989 & 5 & 0 & $0 \%$ & \\
\hline & & 1992 & 12 & 1 & $8.30 \%$ & \\
\hline & Palmira & 2000 & 4 & 1 & $25.00 \%$ & $25.00 \%(4)$ \\
\hline \multirow[t]{3}{*}{ Western } & El Cairo & 1984 & 3 & 0 & $0 \%$ & $10.00 \%(10)$ \\
\hline & & 2001 & 3 & 0 & $0 \%$ & \\
\hline & & 2002 & 4 & 1 & $25.00 \%$ & \\
\hline
\end{tabular}

leucism traits occur with different frequency in both sexes and with different prevalence in the localities we studied, we consider that leucism in A. affinis may be due to genetic factors.

Considering the effects of geographic isolation in the emergence of recessive traits (e. g., bottleneck effect; Bensch et al. 2000; Lopucki and Mróz 2010), our findings suggest that some populations of $A$. affinis might be experiencing inbreeding due to either the discontinuous distribution of this species (Roach 2016) or to habitat fragmentation in the Colombian Andes (Kattan et al. 1994; Kattan and Alvarez-López 1996). According to the International Union for Conservation of Nature (IUCN), A. affinis is listed as Least Concern since a large population is presumed from its wide overall distribution range (Roach 2016). Nevertheless, aside from its distribution, there is scarce information about the population ecology of this species (Pardiñas et al. 2015). Consequently, information on population dynamics and population genetics is needed to determine the conservation status of $A$. affinis.

\section{Acknowledgements}

We are grateful to all those people who over the years have been contributing to the growth and maintenance of the Mammals Collection of Universidad del Valle (UV); without their help, this work could not be possible. We also thank L. Ruano for taking the photographs. Finally, we thank S. T. Álvarez-Castañeda and two anonymous reviewers for their valuable comments. María Elena Sánchez-Salazar edited the English manuscript.

\section{References}

Bensch, S., H. Bengt, D. Hasselquist, and B. Nielsen. 2000. Partial albinism in a semi-isolated population of great reed warblers. Hereditas 133:167-170.

Brito, J., And K. Valdivieso-Berneo. 2016. First records of leucism in eight species of small mammals (Mammalia: Rodentia). Therya 7:483-489.
BuCKLeY, P. A. 1982. Avian genetics. Pp. 21-110 in Diseases of cage and aviary birds, Second edition (Petrak, M., ed.). Lea and Febiger. Philadelphia, USA.

Camargo, I., E. Rios, C. Cornejo-Latorre, and S. T. Álvarez-Castañeda. 2014. First Record of Leucism in the Genus Peromyscus (Mammalia: Rodentia). Western North American Naturalist 74:366-368.

CARO, T. 2005. The adaptative significance of coloration in mammals. BioScience 55:125-136.

Hearing, V. J., and K. Tsukamoto. 1991. Enzymatic control of pigmentation in mammals. FASEB J 5:2902-2909.

Kattan, G. H., and H. Alvarez-López. 1996. Preservation and Management of Biodiversity in Fragmented Landscapes in the Colombian Andes. Pp. 3-18 in Forest Patches in Tropical Landscapes (Schelhas, J., and R Greenberg, eds.). Island Press. Washington, USA.

Kattan, G. H., H. Alvarez-López, and M. Giraldo. 1994. Forest Fragmentation and Bird Extinctions: San Antonio Eighty Years Later. Conservation Biology 8:138-146.

LeVINE, L., AND P. L. KRUPA. 1966. Studies on Sexual Selection in Mice. III. Effects of the Gene for Albinism. The American Naturalist 100:227-234.

LoPUCKI, R., AND I. Mróz. 2010. Cases of colouration anomalies in small mammals of Poland and reasons for their incidence. Annales UMCS, Biologia 65:67-76.

Oetting, W. S., J. P. Fryer, S. Shriram, and R. A. King. 2003. Oculocutaneous albinism Type 1: The last 100 years. Pigment Cell Res 16:307-311.

OlivelRA, S. V. 2009. Albinismo parcial em cutia Dasyprocta azarae (Lichtenstein, 1823) (Rodentia, Dasyproctidae), no sul do Brasil. Biotemas 22:243-246.

Pardiñas, U. F. J., P. Teta, D. F. Alvarado-Serrano, L. Geise, J. P. Jayat, P. E. Ortiz, P. R. Gonçalves, and G. D'Elía. 2015. Genus Akodon. Pp. 144-203 in Mammals of South America Volume 2: Rodents (Patton, J. L., U. F. J. Pardiñas, and G. D'Elía, eds.). The University of Chicago Press. Chicago, USA.

Ramírez-Chaves, H. E., A. F. Suárez-Castro, and J. F. González-Maya. 2016. Cambios recientes a la lista de mamíferos de Colombia. Mammalogy Notes 3:1-9.

ROACH, N. 2016. Akodon affinis. The IUCN Red List of Threatened Species 2016: e.T724A22380499. Available at http://dx.doi. org/10.2305/IUCN.UK.2016-2.RLTS.T724A22380499.en. Downloaded on 14 February 2017.

Velandia-Perilla, J. H., A. P. Yusti-Muñoz, M. A. Sánchez-Martínez, AND A. GIRALDO. 2013. Leucismo en murciélagos de hoja nasal (Chiroptera, Phyllostomidae) de Colombia. Boletín Científico de Museos de Historia Natural 17:87-94.

Associated editor: Lia Méndez

Submitted: May 1, 2017; Reviewed: July 18, 2017;

Accepted:September 10, 2017; Published on line:September 21, 2017. 


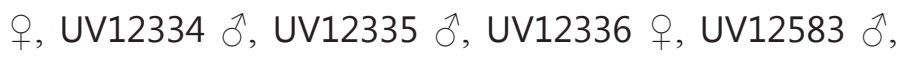

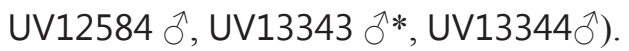

\section{Appendix 1}

Specimens of Akodon affinis, from the Mammals Collection of Universidad del Valle (UV) examined in this study. Specimens marked with an asterisk (*) show traces of leucism.

\section{Central Andes}

Quindío: Reserva Natural La Patasola, Municipality Salento $4^{\circ} 39^{\prime} 32^{\prime \prime}$ N, -75³4' 37" W (UV13267, UV13268, UV13458). Risaralda: Parque Regional Natural Ucumarí, Municipality Pereira, $4^{\circ} 42^{\prime} 7.4^{\prime \prime} \mathrm{N},-75^{\circ} 32^{\prime}$ 05.5' W, 2,130 m (UV10323 §, UV10324 ô, UV10325 ð, UV10326 o, UV10327 ô, UV10328 ô, UV10329 ㅇ, UV10330 ㅇ, UV10331 क, UV10332 ㅇ, UV14437 ô, UV14438 ㅇ, UV14439 $\delta^{\lambda}$, UV14440 $\delta^{*}$, UV14466 ㅇ, UV14467 ㅇ, UV14468 +, UV14487 क, UV14488* $)$; Finca La Selva, vereda El Cedralito, Municipality Santa Rosa de Cabal, $4^{\circ} 47^{\prime} 18^{\prime \prime} \mathrm{N},-75^{\circ} 37^{\prime} 29^{\prime}$ 'W (UV3367 으, UV13052 우, UV13053 §).

Valle del Cauca: Finca Venteaderos, Vereda La Nevera, Municipality Palmira, $3^{\circ} 33^{\prime} 02^{\prime \prime} \mathrm{N},-76^{\circ} 06^{\prime} 51^{\prime}$ 'W, 2,700m (UV12022 ô, UV12023 ô, UV12024 \&, UV12025 ${ }^{*}$ ); Finca Santelina, Vereda El Janeiro, Corregimiento La Habana, Municipality Buga, $3^{\circ} 52^{\prime} 37^{\prime \prime} \mathrm{N},-76^{\circ} 11^{\prime} 57^{\prime \prime} \mathrm{W}$,



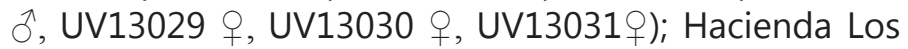
Alpes, Vereda Las Brisas, Municipality Florida, $3^{\circ} 19^{\prime} 18^{\prime \prime}$

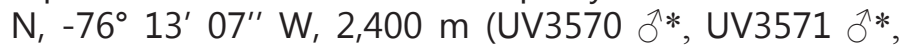

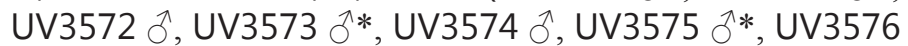
ô, UV3577 क, UV3578 क*, UV10335 ô, UV10336 ô, UV10337 क, UV10338 क, UV10339 क, UV10343 UV10344 ô, UV10345 ㅇ, UV10346 ㅇ, UV10347 ㅇ,

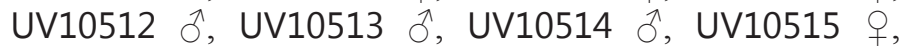



\section{Western Andes}

Valle del Cauca: Campamento Corea, Parque Nacional Natural Farallones de Cali, Municipality Cali, $3^{\circ} 19^{\prime} \mathrm{N}$, -76 39' W (UV2261 ô, UV2589 ô, UV2590 ᄋ, UV2591 + , UV4385 §); Torre de televisión, Cerro La Horqueta, Municipality Cali, $03^{\circ} 29^{\prime} 25^{\prime \prime} \mathrm{N},-76^{\circ} 37^{\prime} 54^{\prime \prime} \mathrm{W}$, 2,250 m (UV8162 今̄, UV8163 ô, UV8164 ㅇ, UV10333

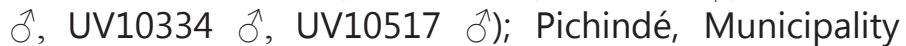
Cali, $3^{\circ} 25^{\prime} 52^{\prime \prime} \mathrm{N},-76^{\circ} 37^{\prime} 6^{\prime \prime} \mathrm{W}$ 1,800 m (UV6621 ô,,

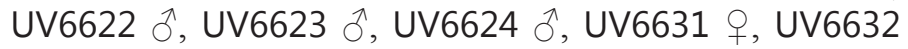
9, UV10613 +); Parcelación El Silencio, vereda La Elvira, Municipality Cali, $3^{\circ} 32^{\prime} 43^{\prime \prime} \mathrm{N},-76^{\circ} 35^{\prime} 44^{\prime \prime} \mathrm{W}, 2,000 \mathrm{~m}$

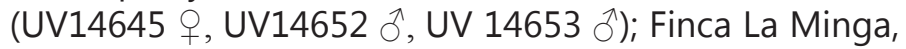
Reserva forestal Bitaco, Vereda Chicoral, corregimiento Bitaco, Municipality La Cumbre, $3^{\circ} 33^{\prime} 69^{\prime \prime} \mathrm{N},-76^{\circ} 35^{\prime}$ 10.1" W, 1982 m (UV14774 ô, UV14775 ô, UV14780 ふ). Alto Galápagos, Municipality El Cairo, $4^{\circ} 49^{\prime} 00^{\prime \prime} \mathrm{N}$, $-76^{\circ} 11^{\prime} 00^{\prime \prime} \mathrm{W}, 2,000 \mathrm{~m}$ (UV4171 ô, UV4172 9 , UV4173 